\title{
Seasonality Of The Monogenean From Some Perciform Fishes İn Iraqi Marine Waters
}

\author{
Suzan A. Al-Azizz ${ }^{1}$, Khalidah S. Al-Niaeem ${ }^{2}$ and Hayder A.H. Al-Hasson ${ }^{1}$ \\ ${ }^{I}$ Department of Microbiology and Veterinary Parasitology, College of Veterinary Medicine, University of \\ Basrah, Iraq \\ ${ }^{2}$ Department of Fisheries and Marine Resources, College of Agriculture, University of Basrah, Iraq
}

\begin{abstract}
A total of 72 fishes, belonging to three species of order perciform fish: Acanthopagrus bifasciatus (Sparidae), Platax orbicularis and P. teira (Ephipidae), which were collected from Iraqi marine waters, during period October 2013 till July 2014. The results showed tow species of monogenean: Sprostoniella multitestis and Lamellodiscus sp. The study included the prevalence and intensity of fish parasites, where there appeared clear differences in respect to fish species, and showed significant differences at $p \leq 0.05$. The present study revealed that the highest prevalence (92.85\%) of infection in P. teira and mean intensity (25.57) of infection in A. bifasciatus and showed the lowest prevalence (78.43\%) in A. bifasciatus and mean intensity (9.33) in P. orbicularis. Significant $(p \leq 0.05)$ differences were noticed in the infection of male (34) and female (25) fish with the parasite. Infection with these monogenean in general showed monthly variation, as it was high during November and January and low during December and June.
\end{abstract}

Keywords: Seasonality, fish, perciform, parasites, monogenean, Iraqi marine waters.

\section{Introduction}

The parasitic diseases affect fish hosts and cause high mortalities in both cultured and wild, and leading to losses which are considered as one of the major barrier against the expanding of fish industry (Menzies et al., 2002). Communities of parasites of marine fish are often unstructured and unpredictable. The main reasons for this community profile are viability, behavior, physiology and feeding habits of the hosts as well as phylogenetic specificity and possible interactions between parasites (Luque et al., 2004).

The monogeneans are group of ectoparasites living on the skin, fins and gills representing the largest group of fish parasites (Onrčkov et al, 2004). They are belonging to phylum Platyheminthes. They cause fish death and mass mortalities associated with large economical losses.

Some ecological information about the monogenetic trematodes of Iraqi marine water fishes were publishes. Information reported in such investigations included the seasonal changes of infection with host age, site of attachment, geographic distribution and correlation of infection with host sex (Al-Daraji and Al-Salim, 1990; Al-Daraji et al, 2010; Jasim, 2013; Al-Hasson, 2015).

\section{Materials And Methods}

A total of 72 fish were collected by fishermen using trawl net monthly, during the period from October 2013 until the end of July 2014, which belong three species of Perciformes fishes: Acanthopagrus bifasciatus (Forsskål, 1775), Platax orbicularis (Forsskål, 1775), P. teira (Forsskål, 1775), they were taken from Iraqi marine water, North west Arab Gulf (latitudes $47^{\circ} 30^{\prime}$ to $48^{\circ} 15^{\prime}$; N $30^{\circ} 50^{\prime}$ to $30^{\circ} 00^{\prime} \mathrm{E}$ ).

The specimens were placed in container filled with small ice pieces and transferred to the laboratory in the Department of Fisheries and Marine Resources, College of Agriculture, University of Basrah, for examination. Fishes were identified according to Carpenter et al. (1997) and updated according to (Froese and Pauly, 2015).

In the laboratory, fish gills were cut out and examined under a dissecting microscope at 40-100x magnification. Vigorously moving worms were separated from the gills with a pipette and samples for light microscopy were handled according to Scholz and Hanzelová (1998). During the study, period data on fish were categorized according to sex of host and months. The terms of prevalence (percentage incidence) and mean intensity of infection were used according to Margolis et al. (1982).

By application of SPSS (version 18), the data were subjected to one-way analysis of variance (ANOVA) to determine the difference between the means and the significant differences were tested by LSD Test.

\section{Results}

The gills of 72 of A. bifasciatus, P. orbicularis and P. teira (Table 1) were infected with monogeneans: S. multitestis and Lamellodiscus sp. The overall prevalence was $81.94 \%$ and the mean intensity of infection was 
1202 (Table 2). As it is indicate from table (3), that the rate of infection was higher (85\%) in male as compared to its rate $(78.12 \%)$ in females, and this difference was significant statistically $(\mathrm{P} \leq .05)$.

A survey of prevalence and mean intensity of A. bifasciatus, $P$. orbicularis and $P$. teira infection with monogeneans on monthly basis is given in (Table 4). It is apparent from this table that these parasites occurred in the fish throughout the year, with prevalence reaching $81.94 \%$. The lower prevalence was during November and May, while the higher prevalence was during October and June. The mean intensity ranged from 3 to 43 during October and January respectively (Table 4).

Table 1.Species of fish with their total numbers and the range of their total length and weight.

\begin{tabular}{|l|l|l|l|}
\hline \multicolumn{1}{|c|}{ Species } & \multicolumn{1}{|c|}{ Total number } & \multicolumn{1}{|c|}{$\begin{array}{c}\text { Total length } \\
(\mathbf{c m})\end{array}$} & \multicolumn{1}{|c|}{$\begin{array}{c}\text { Total weight } \\
\text { (gm) }\end{array}$} \\
\hline Acanthopagrus bifasciatus & 51 & $23.5-42.7$ & $1447-251$ \\
\hline Platax orbicularis & 7 & $42.9-48.9$ & $2459-3831$ \\
\hline P. teira & 14 & $39.2-52.8$ & $2222-5442$ \\
\hline Total & 72 & & \\
\hline
\end{tabular}

Table 2. Infection rate of monogeneans in the gills of three species of the perciform fishes during the present study.

\begin{tabular}{|l|l|l|l|l|l|l|}
\hline \multicolumn{1}{|c|}{ Parasite } & \multicolumn{1}{|c|}{ Host } & $\begin{array}{c}\text { Number of } \\
\text { fish } \\
\text { examined }\end{array}$ & $\begin{array}{c}\text { Number of } \\
\text { fish } \\
\text { fnfected }\end{array}$ & $\begin{array}{c}\text { Prevalence } \\
\text { (\%) }\end{array}$ & $\begin{array}{c}\text { No. of } \\
\text { individual } \\
\text { parasite }\end{array}$ & $\begin{array}{c}\text { Mean } \\
\text { intensity }\end{array}$ \\
\hline \multirow{2}{*}{ S. multitestis } & P. teira & 14 & 13 & 92.85 & 123 & 9.46 \\
\cline { 2 - 8 } & P. orbicularis & 7 & 6 & 85.71 & 56 & 9.33 \\
\hline Lamellodiscussp. & A. bifasciatus & 51 & 40 & 78.43 & 1023 & 25.57 \\
\hline Total & 72 & 59 & 81.94 & 1202 & 20.37 \\
\hline
\end{tabular}

Table 3. Infection rate of monogeneans in the gills of three species of the perciform fishes in both sexes during the present study.

\begin{tabular}{|l|l|l|l|c|c|}
\hline \multicolumn{1}{|c|}{ Fish sex } & $\begin{array}{c}\text { Number of } \\
\text { fish } \\
\text { examined }\end{array}$ & $\begin{array}{c}\text { Number of } \\
\text { fish } \\
\text { infected }\end{array}$ & $\begin{array}{c}\text { prevalence } \\
\text { (\%) }\end{array}$ & $\begin{array}{c}\text { No. of } \\
\text { individual } \\
\text { parasite }\end{array}$ & $\begin{array}{c}\text { Mean } \\
\text { intensity }\end{array}$ \\
\hline Male & 40 & 34 & 85 & 740 & 21.76 \\
\hline Female & 32 & 25 & 78.12 & 462 & 18.48 \\
\hline Both & 72 & 59 & 81.94 & 1202 & 20.37 \\
\hline
\end{tabular}

Table 4. Monthly variation of monogeneans in the gills of three species of the perciform fishes during the present study.

\begin{tabular}{|l|l|l|l|l|l|l|}
\hline \multicolumn{1}{|c|}{ Months } & Fish species & $\begin{array}{c}\text { Number of } \\
\text { fish } \\
\text { examined }\end{array}$ & $\begin{array}{c}\text { Number } \\
\text { of fish } \\
\text { infected }\end{array}$ & $\begin{array}{c}\text { prevalence } \\
\text { (\%) }\end{array}$ & $\begin{array}{c}\text { No. of } \\
\text { individual } \\
\text { parasite }\end{array}$ & $\begin{array}{c}\text { Mean } \\
\text { intensity }\end{array}$ \\
\hline October & P. teira & 5 & 5 & 100 & 14 & 2.8 \\
\hline November & A. bifasciatus & 28 & 18 & 64 & 252 & 14 \\
\hline December & A. bifasciatus & 4 & 4 & 100 & 34 & 8.5 \\
\hline January & A. bifasciatus & 18 & 17 & 94 & 735 & 43.23 \\
\hline May & P. orbicularis & 7 & 6 & 86 & 56 & 9.33 \\
\hline June & P. teira & 9 & 8 & 89 & 109 & 13.62 \\
\cline { 2 - 7 } & A. bifasciatus & 1 & 1 & 100 & 2 & 2 \\
\hline Total & & 72 & 59 & 81.94 & 1202 & 20.37 \\
\hline
\end{tabular}

\section{Dissection}

The susceptibility of fishes to infestation with parasites differs and depends on various factors, including morphology, immunological characteristics and physiology, as well as host-specificity and distribution of the parasite (Nnadi et al., 2011 and Chavez et al., 2012).

According to the studies by Rahman and Thomas (2007) and Buchmann and Lindenstrom (2002) the intensity of fish parasite was greatly influenced by season. Relative condition factor is an indicator of health that also reflects recent nutritional conditions (Gislaine et al., 2011). According to Neffa and Cargnelli (2004) recorded the condition factor like amount of energy was available to an individual which may be allocated to various life functions including reproduction, foraging and over-winter survival. Negative effects on the hosts are expected, because they are inherent in parasitism, these effects have a direct influence on the reproduction 
and feeding conversion efficiency, and therefore on the maintenance of health (Gibbs, 1985). The possible effects those pathogens hade on their hosts are difficult to assess or quantify, especially in fish under natural conditions.

In the present study males had higher prevalence and intensity than females. This can be attributed to the inactive of females since most of them had ripe gonads indicating a spawning period. Spawning fish tend to be inactive reducing the chances of contacting the infective stages of the parasite, changes in the level of hormone, could be considered as a factor reducing the number of parasite in females, also can be attributed because high number of exam male differently with female fish (Barber et al., 2000 and Chacha and Hieromin, 2014). On the other hand some authors gave examples on the similarity of food and feeding habits, living in the same habitat, and the absence of the morphological differences between male and female of fishes provides evidences on the similarity of the infection with parasites (Dogiel, 1961).

The parasites were increased during spring and summer due to their reproduction during these seasons, they deposit their eggs directly into the water. The motile ciliated larvae hatch out and after a short freeswimming period it will settle on the fish, on which they reach the stage of sexual maturity (Kennedy, 1975).

\section{References}

[1]. Al-Daraji, S.A.M. \& Al-Salim, N.K. (1990). Parasitic fauna of five species of fishes from Al-Hammar marsh, Iraq. I: Protozoa and Monogenea. Mar. Mesopot., 5(2): 275-282.

[2]. Al-Daraji, S.A.M.; Bannai, M.A.A. and Abbas, A.A.K. (2010). Some parasites of the yellow- finned sea bream Acanthopagrus latus (Houttuyn, 1782) in the Iraqi marine waters. Iraqi J. Aquacult., 7(2): 115-122.

[3]. Al-Hasson, H.A.H. (2015). Taxonomical and pathological studies on parasites of some perciforme fishes in Iraqi marine waters. M. Sc. Thesis. Veterinary Coll., Basrah Univ., 162pp.

[4]. Barber, I., Hoare, D. and Krause, J. (2000). Effects of parasites on fish behavior: A review and evolutionary perspective. Rev. Fish Biol. Fish., 10: 131-165.

[5]. Buchmann, K. and Lindenstromn, T. (2002). Interactions between monogenean parasites and their fish hosts. Int. J. Parasitol., 32: 309-319.

[6]. Carpenter, K.E., Krupp, F., Jones, D.A. and Zajonz, U. (1997). FAO species identification field guide for fishery purposes living marine resources of Kuwait, eastern Saudi Arabia, Bahrain, Qatar, and the United Arab Emirates. FAO, Rome, 293pp.

[7]. Chacha, J. M. and Hieromin L. (2014). Population biology of the metazoan parasites infecting fishes from Lakes Uba and Ruwe, Lower Rufiji Floodplain, Tanzania. Nat. Sci., 6: 700-708.

[8]. Chavez, D.J.; LeVan, I.K.; Miller, M.W. and Ballweber, L.R. (2012). Baylisascaris procyonis in raccoons (Procyon lotor) from eastern Colorado, an area of undefined prevalence. Vet. Parasitol., 185: 330-334.

[9]. Dogiel, V.A. (1961). Ecology of the parasites of fresh water fishes”. In: Dogiel, V.A.; Petrushevski, G. K. and Polyanski, Yu. I. (Eds.) Parasitology of fishes (Engl. Transl.). Oliver and Boyd Ltd., Edinburgh and London, 1-47.

[10]. Froese, R. and Pauly, D. (eds.) (2015). FishBase. World Wide Web electronic publication. www.fishBase.org. (Version May2015).

[11]. Gibbs, H.C. (1985). Effects of parasites on animal and meat production. In: Gaafar, S.M., Howard, W.E. and Marsh, R.E. (Eds.), World Animal Science: Parasites, Pests and Predators. Elsevier, Holanda, pp. 7-27.

[12]. Gislaine, G.; Gomes, W.L.; Tavechio, R.; Massato, T. and Pavanelli, G.C. (2011). Relative condition factor and parasitism in anostomid fishes from the floodplain of the Upper Paraná River Brazil. Vet. Parasitol., 177 (1-2): 98.

[13]. Jasim, A.A.R. (2013). Study on some parasites of Acanthopagrus latus and disease agents of two penaeid shrimps from Iraqi coastal waters. Ph. D. Thesis, Agriculture Coll, Basrah Univ., 127pp.

[14]. Kennedy, C. R. (1975). Ecological animal parasitology. Blackwell Sci. Publ., Oxford, 163pp.

[15]. Luque, J.L., Mouillot, D. and Poulin, R. (2004). Parasite biodiversity and its determinants in coastal marine teleost fishes of Brazil. Parasitology, 128(5): 671-682.

[16]. Margolis, L.; Esch, G.W.; Holmes, J.C.; Kuris, A.M. and Schad, G.A. (1982). The use of ecological terms in parasitology (Report of an ad hoc committee of the American Society of Parasitologists). J. Parasitol., 68(1): 131-133.

[17]. Menzies, F.D.; Crockford, T.; Breck, O. and Midtlyng, P.J. (2002). Estimation of direct costs associated with cataracts in farmed Atlantic salmon (salmo salar). Bull. Eur. Ass. Fish Pathol., 22: 27-32.

[18]. Neffa, B.D. and Cargnellib, L. M. (2004). Relationships between condition factors, parasite load and paternity in bluegill sunfish, Lepomis macrochirus. Environ. Biol. Fish., 71: 297-304.

[19]. Nnadi, E.I.; Awi-waadu, G.D.B. and Imafidor, H.O. (2011). Association between parasitic infection and fish habitat, Jorind, (9)1: 186-190.

[20]. Onrčkova, M.; Matějusova, I.; Šmikov, A. and Gelnar, M. (2004). New reports of dactylogyridean species (Monogenea) for Central Europe. Helminthologia, 41(3): 139-145.

[21]. Özer, A. and Öztürk, T. (2005). Dactylogyrus cornu Linstow, 1878 (Monogenea) infestations on Vimba ((Vimba Vimba tenella (Nordmann, 1840)) caught in the Sinop region of Turkey in relation to the host factors. Turk. J. Zool., 28: 179-182.

[22]. Rahman, M.S. and Thomas, P. (2007). Molecular cloning, characterization and expression of two hypoxia-inducible transcription factors (HIF-1a andHIF-2a) in a hypoxia tolerant marine teleost, Atlantic croaker (Micropogonias undulatus). Gene, 396: 273-282.

[23]. Scholz, T. and Hanzelova, V. (1998). Tapeworms of the genus Proteocephalus Weinland, 1858 (Cestoda: Proteocephalidae), parasites of fishes in Europe. Studie AV C` R, No. 2/98. Prague, Czech Republic: Academia, 119 pp. 